\title{
HARDWARE VIRTUAL INFRASTRUCTURE
}

\section{Milan KLEMENT}

Abstract: The article treats the role of a new item in the development of local computer networks. It describes possible modes of virtualization of the hardware level of computer networks built on the VMWare ESX server basis.

Key words: network infrastructure, hardware, service provided by a computer network, ESX server.

\section{HARDWAROVÁ VIRTUÁLNÍ INFRASTRUKTURA}

Resumé: Článek se zabývá úlohou nového prvku ve vývoji lokálních počitačových sití. Popisuje možné způsoby virtualizace hardwarové vrstvy lokálních počitačových sití postavených na platformě VMWare ESX serverů.

Klíčová slova: sitová infrastruktura, hardware, služby počitačové sitě, ESX server.

\section{1 Úvod}

Problematika správy rozsáhlé počítačové sítě se v v dnešní době dostává do popředí zájmu mnoha správců počítačových sítí. Závazným problémem je zejména časově a finančně náročná údržba hardwarové vrstvy počítačové sítě a to zejména hardware a software serverů. Aktivní prvky počítačové sítě (router, switch a bridge) jsou ve většině př́ípadů tvory pasivními součástkami a jsou navrženy pro stálý a nepřetržitý provoz. Pokud je třeba rozšśríit kapacitu počítačové sítě, jsou tyto kapacity navyšovány instalací nových aktivních prvků a ne zvyšováním jejich kapacity, což není ano dost dobře možné.

Jiná situace ale panuje v oblasti serverů. Servery jsou zařízení, které obsahují celou řadu mechanických a pohyblivých částí, které se časem opotřebují a třeba je nahradit. Hardwarový výpadek serveru je nepř́ijemný především s ohledem na nedostupnost služeb na něm provozovaných a také sohledem na časovou nedostupnost náhradních počítačových komponent. Velkým problém je také rozšiřování kapacit a objemu poskytovaných služeb, které jsou zpravidla dosahovány upgrade stávajících serverů.

Je také známé pravidlo správců počítačových sítí: „co služba to hardwarový server". Toto pravidlo má své opodstatnění, protože při výpadku serveru, na kterém je dislokováno více služeb může dojít $\mathrm{k}$ destabilizaci celé počítačové sítě a tím k zamezení poskytování jednotlivých služeb klientům. Proto je nutné některé služby duplikovat a tím roste počet hardwarových serverů.

Na základě těchto informací je možné říci, že provoz a údržba infrastrukturních sít'ových serverů, s ohledem na časovou a finanční náročnost, je problémem, který se stále více projevuje i v malých či středních lokálních sítích. Možností jak tento problém odstranit je nasazení virtualizační vrstvy realizované VMWare ESX serverem.

\section{VMWare ESX server}

Použití technologie vizualizace pomocí VMWare ESX serverů je atraktivním a vyžadovaným řešením, které umožňuje snížení celkového počtu fyzických serverů a efektivní využití a přerozdělování jejich výpočetního výkonu. Tradiční způsob nasazení serveru je jeho dedikování na jeden primární účel (často prímo výrobce aplikace požaduje vyhrazení serveru pro odstranění potenciálních problémů poskytované služby). Takové nasazování vede $\mathrm{k}$ neefektivnímu nasazení serverů a neefektivnímu využívání hardwarových zdrojů, kde je např́iklad u Intel serverů běžné využívání zdrojů serverů maximálně na úrovni $10-15 \%$.

VMware ESX Server VMware ESX Server je softwarové řešení pro konsolidaci a řízení systémů V nasazení kritických aplikací. VMware ESX Server urychluje nasazení servisního managementu vytvářením bezpečných, vzájemně přenositelných hardwarově nezávislých virtuálních serverů. 
VMware ESX Server zásadně zvýší dostupnost kritických aplikací a rychlost obnovy serverů při výpadku.

\section{Klasické pojetí dedikování serveru}

Klasické dedikování služby na jeden fyzický server, které je patrné z níže uvedeného obrázku č. 1. s sebou nese celou řadu nevýhod, které velmi výrazně zatěžují rozpočet škol či firem a to jak finančně tak časově.

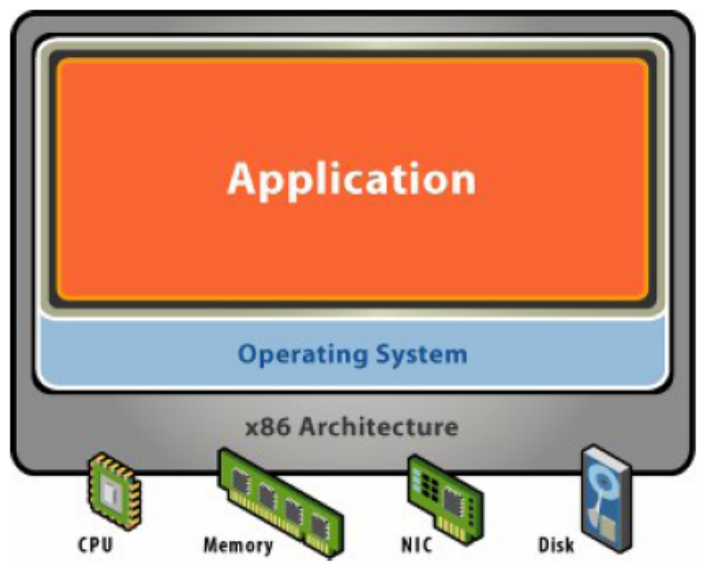

Obr. 1: Klasické dedikování serveru.

Jasnou nevýhodou tohoto řešení je skutečnost, že provozovaná služba nevyužije všech kapacit hardware a pokud je třeba uvedenou službu duplikovat, jako je tomu například $v$ prrípadě řadičů domén či DNS serverů, vroste počet provozovaných serverů. Druhou možností je přetížení hardware serveru v důvodu vysokých nároků provozované služby. I v tomto př́padě je nutné pořizovat další hardwarový server a službu provozovat $\mathrm{v}$ jejich clusteru.

\section{Virtualizační pojetí dedikování serveru}

Pokud je do struktury sítě včleněn ESX server může dojít k virtualizaci určitých hardwarových serverů v tomto systému. Způsob dedikování služeb na jednotlivé virtuální servery uvádí níže uvedený obrázek č. 2.

Jasnou výhodou tohoto řešení je optimalizace provozu jednotlivých virtuálních serverů, protože je možné zajistit, aby virtuální stroj používal pouze tolik hardwarových prostředků kolik je třeba. Ostatní prostředky je možné alokovat pro použití jiným virtuálním strojem. Další výhodou je snížení počtu fyzických serverů a tím výrazná úspora finančních prostředků při jejich obnově či údržbě.
Všechny hardwarové zdroje virtuálního řešení jsou sdíleny jednotlivými virtuálními servery a $\mathrm{v}$ př́ípadě kolize či neočekávaného nárůstu výkonu je možné virtuálním serverům přidělovat rezervní kapacitu hardwarových

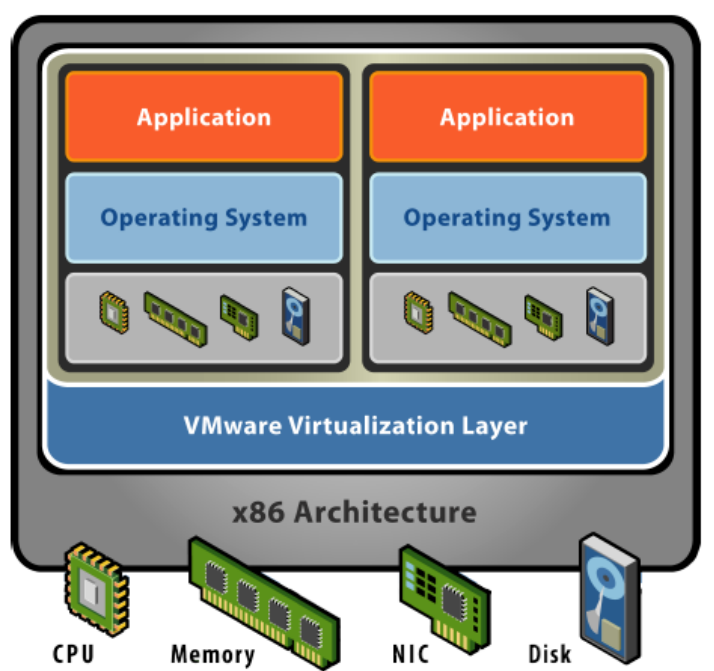

Obr. 2: Virtualizační dedikování serveru.

prostředků. Proto je doporučováno, provozovat alespoň 2 ESX servery na dvou fyzických serverech v clusteru. Tuto situaci uvádí níže uvedený obrázek číslo 3.
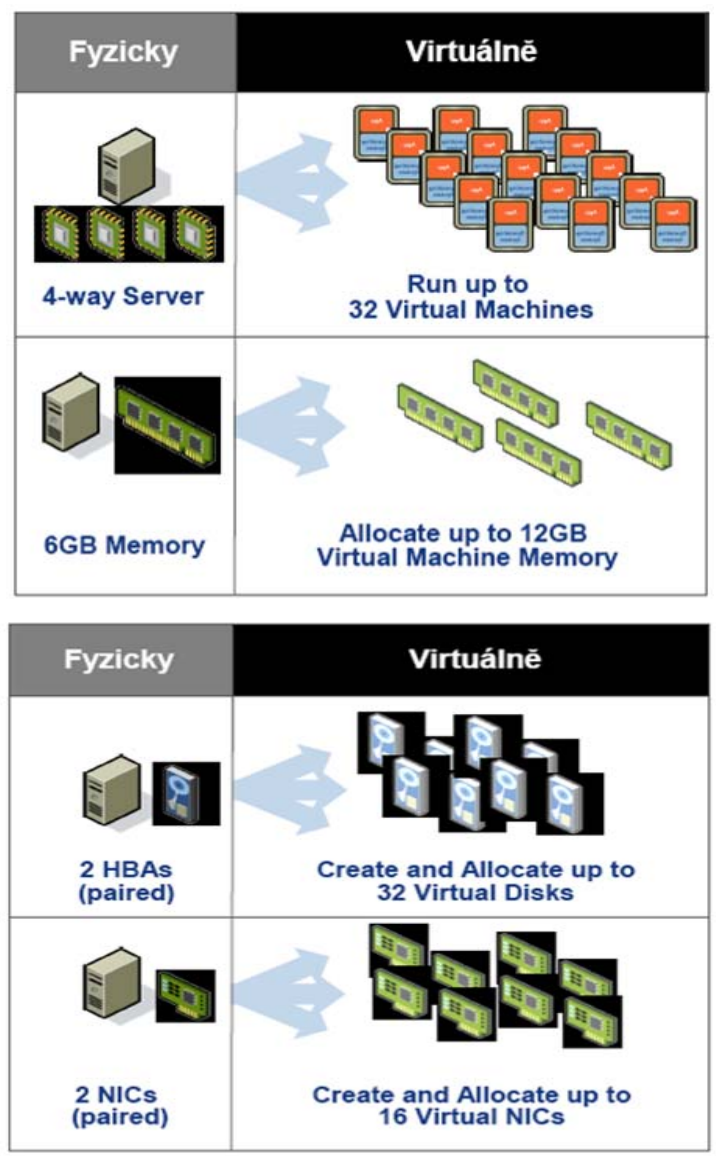

Obr. 3: Sdílení hardwarových prostředkì. 
5 Podporované operační systémy pro provoz na ESX serveru

Z hlediska software je možné ve virtuálním stroji provozovat jakýkoliv operační systém určený pro platformu x86. Přehled jednotlivých operačních systémů uvádí tabulka číslo 1.

\section{Závěr}

Virtualizace hardwarové infrastruktury počítačové sítě umožňuje výrazným způsobem snížit náklady spojené s provozem a údržbou počítačové sítě. Umožňuje také podstatné snížení počtu fyzických serverů a tím snížení rizika výpadku služeb počítačové sítě v důsledku selhání hardware serveru.

Vhodným řešením je nasazení několika ESX serverů a použití synchronizační konzoly MMC, která umožňuje přesunutí jednotlivých virtuálních serverů $\mathrm{z}$ jednoho ESX serveru na druhý. Tímto opatřením se úplně eliminuje možnost nedostupnosti služby $\mathrm{v}$ důsledku selhání hardware.

\section{Literatura}

(1) WWW Build the Foundation of a Responsive Data Center, VMWare, 20022007. [cit. 2007-30-4]. Dostupný z: <URL: http://www.vmware.com/products/vi/ esx/>.

(2) WWW VMware ESX Server, ITWeek, 2006-2007. [cit. 2007-30-4]. Dostupný z: <URL: http://www.itweek.co.uk/itweek/soft ware $/ 2085877 /$ vmware-esx-server>.

PhDr. Milan Klement, Ph.D.

Katedra technické a informační výchovy

Pedagogická fakulta UP

Žižkovo nám. č. 5, 77140

Olomouc, $\check{\mathbf{C}} \mathbf{R}$

tel: + 420585635811 , e-mail: milan.klement@upol.cz

\begin{tabular}{|l|l|}
\hline & $\begin{array}{l}\text { Windows Server 2003 Standard, Enterprise, } \\
\text { Web Editions, and Small Business Server }\end{array}$ \\
\hline & Windows 2000 Server and Advanced Server \\
\hline & Windows NT: 4.0 Server \\
\hline & Windows XP Professional \\
\hline & $\begin{array}{l}\text { Red Hat Linux 7.2, 7.3, 8.0, \& 9.0 } \\
\text { Red Hat Enterprise Linux 21 }\end{array}$ \\
\hline & Solaris 10 (on x86) \\
\hline SuSE Linux 8.2, 9.0 and 9 \\
\hline
\end{tabular}

Tabulka 1: Podporované operačni systémy. 